всех: политика и практика инклюзии: сборник научных статей и научно-методических материалов. - Саратов: Научная книга, 2008. - 445 с.

УДК377.3.015.311

Ольга Сюсова

\title{
УСТАНОВЛЕННЯ ВИМОГ ДО ОСОБИСТІСНИХ ЯКОСТЕЙ КВАЛІФІКОВАНОГО РОБІТНИКА
}

\author{
Єжова О. В. Установлення вимог до особистісних якостей кваліфікованого \\ робітника.
}

Робота спрямована на встановлення науково обгрунтованого переліку індивідуальних особливостей особистості, необхідних для успішного набуття професійних компетенцій робітників-швейників. Установлено, що представникам усіх досліджуваних професій потрібні якості типу «людина-техніка», а для деяких завдань - «людина-людина» та «людина-художній образ». Створений перелік охоплює 39 професійно важливих якостей особистості, у результаті апріорного ранжування список скорочений до 33-х.

Ключові слова: професійно важливі якості, швачка, кравець, закрійник, оператор швацького устаткування.

Ежова О. В. Установление требований к личностным качествам квалифицированного рабочего.

Работа направлена на установление научно обоснованного перечня индивидуальных особенностей личности, необходимых для успешного формирования профессиональных компетенций рабочих-швейников. Установлено, что представителям всех исследуемых профессий необходимы качества типа «человектехника», а для некоторых заданий - «человек-человек» и «человек-художественный образ». Созданный перечень включает 39 профессионально важных качеств, в результате априорного ранжирования список сокращен до 33-х.

Ключевые слова: профессионально важные качества, швея, портной, закройщик, оператор швейного оборудования.

Yezhova O. V. Setting out requirements for the personality qualities of a skilled worker.

The article is aimed at establishing a scientifically substantiated list of personality traits necessary for the successful forming professional competences of garment workers. The author determined that people of these occupations require such qualities as «person-totechnique» and for some tasks - «person-to-person» and «person-to-artistic image». This list includes 39 professionally important qualities; the list was reduced to 33 qualities as a result of a priori ranking.

Key words: professionally important qualities, seamstress, tailor, tailor's cutter, sewing equipment handler.

Успіх професійної діяльності значною мірою залежить від відповідності обраної професії та індивідуальних якостей працівника. Характер та ступінь розвиненості професійно важливих якостей зумовлюють, в числі інших чинників, професійну надійність працівника. У зв'язку з цим актуальним є завдання встановлення науково обгрунтованого переліку індивідуальних особливостей особистості, необхідних для 
успішного набуття професійних компетенцій.

У психології професійної придатності виокремлюють поняття «професійно важливі якості» суб'єкта діяльності. Це сукупність психологічних якостей особистості, а також низка фізичних, антропометричних, фізіологічних характеристик людини, які визначають успішність навчання та реальної діяльності [2, с. 153].

Відомі численні дослідження, спрямовані на встановлення критеріїв, що максимально враховують відповідність особистості та професії й визначають так звану професійну придатність. Це роботи психологів праці (С. Богословський, В. Лоос, Г. Мюнстерберг; І. Тітова; В. Чебишева,), педагогів (М. Анісімов, А. Ашеров, М. Громкова, Р. Макаров), соціологів. Розроблена Д. Патерсоном класифікація 432 професій містить кілька фахівців швейної галузі, від фахівців високої кваліфікації (наприклад, інженер-технолог) до помічника швачки.

Аналізуючи вказану класифікацію, відзначаємо, що автор установив високі вимоги до рівня академічних та механічних здібностей працівників швейної промисловості, які підвищуються для фахівців-технологів (АА), майстрів та дизайнерів (BВ). Для кваліфікованих робітників, зокрема швачок та кравців, ці вимоги помірні (CC). Для помічника швачки та продавця-кравця встановлені мінімальні вимоги до рівня академічних та механічних здібностей (DD). Мистецькі здібності важливі для дизайнерів одягу (B) та швачок $(\mathrm{C})$. Для решти професій достатньо мінімального рівня (D). Соціальних здібностей, за класифікацією Д. Патерсона, вимагає робота майстра (B), дизайнера високоякісного одягу та кваліфікованої швачки (C). Для решти професій установлений мінімальний рівень (D). Такий підхід досить суперечливий, оскільки робота кравця та продавця передбачає спілкування з замовниками, а отже не слід очікувати успішної діяльності за відсутності соціальних умінь у цих робітників. Можливо, специфіка функцій представників названих професій у Британії 1953 р. дещо відрізнялася від сучасних обов'язків кравців.

Із часів створення аналізованої класифікації минуло більше, ніж півстоліття, за цей час змінилось обладнання та кваліфікаційні характеристики працівників швейної промисловості. Однак урахування академічних та механічних здібностей під час відбору та підготовки кваліфікованих робітників швейної галузі актуально й нині.

М. Анісімов, розглядаючи методологічні підходи в розроблення моделей навчального процесу, виокремив, окрім знань, навичок i вмінь, специфічні властивості, які характерні тільки для електрорадіотехнічних професій [1, с. 294]. До них віднесені загальні специфічні вимоги, інтелектуальні вміння, психологічні особливості- разом 27 вимог. Уважаємо такий підхід оптимальним, оскільки структурування вимог до фахівця дозволяє визначити найбільш вагомі його властивості.

Для успішної діяльності модельєра академік Є. Романова вважає необхідними творчі та художні здібності; розвинене просторово-об'ємне мислення, пам'ять та уяву, гарний окомір, почуття гармонії та смаку; здатність сприймати та розрізняти широкий спектр кольорів, гарний розвиток дрібної моторики рук тощо- всього 19 характеристик [5, с. 219]. Більшість вказаних якостей потрібні й кваліфікованим робітникам, особливо закрійникам, які виконують як творчі завдання (створення образу замовника), так і практично втілюють створений ескіз під час розкроювання матеріалу.

Зважаючи на широке застосування нових технологій у виробництві швейних виробів, недостатньо дослідженим $є$ питання встановлення переліку професійно важливих якостей для кваліфікованих робітників- швачки, кравця, закрійника, 
оператора швацького устаткування.

Метою статті є встановлення найбільш суттєвих професійно важливих якостей кваліфікованих робітників швейної галузі. Для реалізації поставленої мети визначено такі завдання:

- аналіз літератури, присвяченої професійному відбору;

- встановлення класифікаційних ознак праці швейників;

- розроблення переліку професійно важливих якостей робітників швейної галузі за наслідками аналізу літературних джерел;

- установлення найбільш суттєвих вимог до робітників шляхом психологічного експерименту.

Для визначення особистісних рис, притаманних представникам професій швейної галузі, була корисною теорія професійного вибору Дж. Холланда, згідно 3 якою всі люди розподіляються на шість типів: реалістичні (Р), інтелектуальні (I), соціальні (С), конвенціальні (К), підприємливі (П) та артистичні (А) [3, с. 19].

На перший погляд, професії швейної галузі відносяться до так званого «реалістичного» типу, оскільки пов'язані 3 технікою, спрямовані на розв'язання конкретних завдань із виготовлення матеріальних предметів - швейних виробів. Для людей, які обирають такі професії, за теорією Холланда, повинні бути притаманні такі особливості особистості та здібності: активність; діловитість; наполегливість; раціональність; практичне мислення; координованість; просторове уявлення; технічні здібності.

Однак, якщо робітники промислових підприємств безпосередньо не контактують зі споживачами їх продукції, то у сфері побутового обслуговування населення комунікації 3 замовником - це невід’ємний складник професійної діяльності закрійника та кравця. Отже, ці професії частково можна віднести й до «соціального» типу. Представникам цих професій повинні бути притаманні такі якості, як вміння спілкуватись; гуманність; пристосування; розв’язання проблем $з$ опорою на емоції та почуття; мовні здібності.

Класичною вважається класифікація професій академіка Є. Климова, створена для інформаційного забезпечення професійного самовизначення молоді. Ним розроблена чотириярусна класифікація за чотирма ознаками: особливостями предмета, цілей, засобів та умов праці.

Так, відповідно до різновидів об'єктних систем (перший ярус класифікації) виокремлено чотири типи професій [4, с. 160]. Згідно $з$ цією класифікацією робітничі професії швейної галузі відносяться до типу «людина-техніка та нежива природа (Т)». Однак професійні обов'язки кравця й особливо закрійника передбачають спілкування 3 замовником під час обговорення моделі, вимірювання розмірних ознак, примірювань. Отже, ці професії мають ознаки, притаманні типу «людина-людина (Ч)». Слід зазначити, що під час створення нових моделей одягу, які суттєво відрізняються від типових конструктивно-декоративних рішень, закрійник постає в ролі митця, і його діяльність може бути віднесена до типу «людина-художній образ $(\mathrm{X}) »$.

У межах кожного типу залежно від цілей діяльності на другому рівні класифікації Є. Климовим визначено три класи професій [4, с. 162]. Згідно 3 цим рівнем класифікації, професії швачки, оператора і кравця можуть бути віднесені до класу перетворювальних (П), а професія закрійника- до дослідницьких (И). Виконуючи обов'язки контролера матеріалів, виробів та лекал, робітник стає представником гностичної (Г) професії.

У межах кожного класу на третьому рівні класифікації за ознакою засобів праці 
виокремлено чотири відділи професій [4, с. 162-163]. Розглядаючи професії швейної галузі в контексті класифікування їх за ознакою засобів праці, ми встановили, що за чинної моделі організації швейного виробництва можна говорити про оснащення не професії, а робочого місця для виконання конкретної операції швачкою, кравцем, закрійником. Залежно від установленого обладнання та особливостей конкретної моделі робітники можуть виконувати операції з використанням ручного інструменту $(\mathrm{P})$, швейних і розкрійних машин (М) та напівавтоматів (А). Чітко класифікувати за вказаною ознакою можна лише професію оператора швацького обладнання, оскільки в кваліфікаційних вимогах цієї професії визначений тип обладнання - автоматичне та напівавтоматичне швейне та розкрійне устаткування (А).

На четвертому ярусі професії класифіковані за умовами праці на чотири групи. За умов правильної організації робочих місць та впровадження систем контролю мікроклімату (опалення, вентиляції тощо) робітники швейної галузі працюють в умовах мікроклімату, близьких до побутових (Б). Узагальнивши результати аналізу професій швейної галузі за чотириярусною психологічною класифікацією професій Є. Климова, ми створили «формули професій» (табл. 1).

Таблиия 1

Формули професій швейної галузі (за класифікацією С. Климова)

\begin{tabular}{|l|c|c|c|c|}
\hline \multicolumn{1}{|c|}{ Професія } & Швачка & Кравець & Закрійник & $\begin{array}{c}\text { Оператор } \\
\text { швацького } \\
\text { устаткування }\end{array}$ \\
\hline Група(умови) & Б & Б & Б & Б \\
\hline Відділ(засоби) & Р, М, А & Р, М, А & Р, М, А & А \\
\hline Клас (цілі) & П & П & И & П \\
\hline Тип (об'єкти) & $\mathrm{T}$ & $\mathrm{T}, \mathrm{Ч}$ & $\mathrm{T}, \mathrm{Ч}, \mathrm{X}$ & $\mathrm{T}$ \\
\hline
\end{tabular}

Аналізуючи отримані «формули професій» (табл. 1), відзначаємо, що представникам усіх досліджуваних професій швейної галузі потрібні якості типу «людина-техніка». Для спілкування з замовниками кравцю та закрійнику повинні бути притаманні особливості, характерні для професій типу «людина-людина» [4, с. 186 -188]. Для створення художнього образу засобами композиції костюма закрійник повинен відповідати вимогам, які висуваються до фахівців професій типу «людинахудожній образ».

Професор Н. Левитов визначив, що для ефективної роботи швачка повинна мати розвинений окомір, гарну кольорову чутливість, тонку дотикову чутливість пальців рук, кінестетичну чутливість м'язів, особливо правої руки, гарний розподіл та перемикання уваги, жвавість та точність уявлення фігур та форм, зорово-рухову координацію, точність спрямування та форми руху руки.

Професія оператора швацького устаткування відносно нова для швейної галузі, однак $\epsilon$ низка наукових праць, спрямованих на психологічне дослідження діяльності операторів різних систем.

Професор А. Конопкін визначив вимоги, які висуває перед людиною діяльність оператора: абсолютна безпомилковість дій; уміння здійснювати екстрені дії; висока особиста відповідальність за свої дії з керування системою; розподілення уваги; обсяг оперативної пам'яти; значна емоційна стійкість.

Підсумовуючи проведений аналіз досліджень в галузі психології праці, професійної придатності та професійного самовизначення, нами встановлений попередній перелік професійно важливих якостей для кваліфікованих робітників швейної галузі: 
- Виконавчо-рухові вияви: точність та швидкість рухів, переважно дрібних; координація та обдуманість рухів, наявність численних рухових навичок.

- Пізнавальні процеси: високі вимоги до уваги, іiї зосередження, розподілу, перемикання. Високі вимоги до гостроти зору; розвинене сприйняття кольору; окомір. Вимоги до відчуття дотику, м'язової чутливості.

- Пам'ять та мислення: високі вимоги. Гарна оперативна пам'ять та мислення. Просторове уявлення, практичне мислення.

- Емоції: емоційна стриманість; стійкість у надзвичайних ситуаціях; підвищене почуття відповідальності.

- Ділові якості та ставлення особистості (до оточуючих, до праці, до речей, до себе): здатність працювати самостійно та в колективі, вміння спілкуватись; мовні здібності; гуманність; акуратність; прагнення до вдосконалення своїх знань та вмінь; сумлінність; раціональність; технічні здібності; дисциплінованість; зібраність; терпіння; здатність неодноразово переробляти зроблене.

- Творчі особливості: уява, нестандартне мислення, фантазія, гнучкість мислення, естетичне почуття, відчуття красивого, інтерес до моди.

- Специфічні вимоги: фізична витривалість під час виконання різної роботи (наприклад, запуск, пакування, особливо виробів пальтово-костюмного асортименту). Специфічні вимоги до оператора: абсолютна безпомилковість дій; уміння здійснювати екстрені дії; висока особиста відповідальність за свої дії з керування системою.

Наведений вище перелік передбачає властивості особистості, які забезпечують успішність виконання робіт у системі «людина-техніка», виконання творчих та пошукових завдань, спілкування з людьми - як колегами, так і замовниками, а також виконання операторських функцій. При цьому узагальнені та укрупнені деякі схожі вимоги до фахівця, сформульовані різними авторами. Наприклад, «ручна вправність» майже ідентичне «наявності численних рухових навичок» тощо.

Установлений в результаті аналізу публікацій перелік охоплює 39 якостей особистості, умовно об'єднаних у 7 груп. У такому вигляді він є занадто громіздким для проведення анкетування. Задля відбору найбільш суттєвих властивостей особистості проведений психологічний експеримент методом апріорного ранжування чинників.

У цьому дослідженні метод апріорного ранжування чинників реалізований шляхом опитування експертів. Кожен експерт заповнив анкету, розроблену відповідно до рекомендацій соціології.

До експертної групи увійшли висококваліфіковані фахівці швейної галузі та професійно-технічної освіти. Усі експерти мають вищу освіту - технічну або педагогічну, три експерти здобули дві вищі освіти. Зіставляючи результати анкетування за чотирма професіями, відзначаємо, що експерти одностайно надали низький для всіх професій ранг таким чинникам: наявність численних рухових навичок; стійкість у надзвичайних ситуаціях; гуманність; здатність неодноразово переробляти зроблене; відчуття красивого; уміння здійснювати екстрені дії.

Це дозволяє вилучити названі чинники 3 подальшого дослідження для всіх професій. Решта факторів передбачувано отримали різні підсумкові ранги для різних професій, що зумовлено відмінностями у змісті, предметі, цілях та засобах праці.

Аналізуючи отримані «формули професій» робітників швейної промисловості, встановлено, що представникам усіх досліджуваних професій потрібні якості типу «людина-техніка». Для спілкування 3 замовниками потрібні якості типу «людина- 
людина», а для створення художнього образу - «людина-художній образ». Створений у результаті аналізу публікацій перелік професійно важливих якостей кваліфікованих робітників швейної галузі передбачає 39 якостей особистості. Вони умовно об'єднані в 7 груп: виконавчо-рухові вияви; пізнавальні процеси; пам'ять та мислення; емоції; ділові якості; творчі особливості; специфічні вимоги. Проведене апріорне ранжування чинників дозволило скоротити перелік до 33 якостей особистості. Подальше дослідження буде спрямоване на встановлення остаточного переліку професійно важливих якостей для кожної з професій: швачки, кравця, закрійника, оператора швацького устаткування.

\section{Література}

1. Анісімов М. В. Теоретико-методологічні основи прогнозування моделей у професійно-технічних навчальних закладах: [монографія] / М. В. Анісімов. - КиївКіровоград: ПОЛІУМ, 2011. - 464 с. 2. Бодров В. А. Психология профессиональной пригодности: [учеб. пособ. для вузов] / В. А. Бодров. - М. : ПЕР СЭ, 2001 - 511 с. 3. Ильин Е. П. Дифференциальная психология профессиональной деятельности / Е. П. Ильин. - СПб. : Питер, 2008. - 310 с. 4. Климов Е. А. Психология профессионального самоопределения / Е. А. Климов. - М. : Издательский центр «Академия», 2004. - 304 с. 5. Романова Е. С. 99 популярных профессий. Психологический анализ и профессиограммы / Е. С. Романова. - [2-е изд.]. - СПб. : Питер, 2003. - 464 с.

УДК 004.054:37.026

Вікторія Іванченко

\section{МЕТОДОЛОГІЧНИЙ АСПЕКТ ОЦНЮВАННЯ НАВЧАЛЬНИХ ДОСЯГНЕНЬ СТУДЕНТІВ ІЗ ВИКОРИСТАННЯМ ТЕСТОВОГО КОНТРОЛЮ}

Іванченко В. О. Методологічний аспект оцінювання навчальних досягнень студентів із використанням тестового контролю.

У статті розглянуто основні методологічні аспекти оцінювання навчальних досягнень студентів ВНЗ із використанням тестового контролю знань. Розкрито основні положення процесу вимірювання якості знань за допомогою тестового контролю.

Ключові слова: методологічні аспекти, оцінювання знань, тестовий контроль, процес вимірювання, якість знань.

Иванченко В. А. Методологический аспект оценивания учебных достижений студентов с использованием тестового контроля.

В статье рассмотрены основные методологические аспекты оценки знаний студентов вузов с использованием тестового контроля знаний. Раскрыты основные положения процесса измерения качества знаний с помощью тестового контроля.

Ключевые слова: методологические аспекты, оценивание знаний, тестовый контроль, процесс измерения, качество знаний.

Ivanchenko V. O. Methodological aspect of assessing students' achievements using a test check.

This article describes the principle methodological aspects of estimating higher school students' knowledge using a test check. The author reveals the main items of the process of measuring the quality of knowledge through a test check.

Key words: methodological aspects, assessment, test check, measurement process, the 